\title{
Integration of physical, chemical and biological methods for the treatment of palm oil mill effluent
}

\author{
Oyakhilome Gloria Irenosen ${ }^{1,}$, , Adefemi Samuel Oluyemi ${ }^{1}$, Akinola Olufemi Korede ${ }^{2}$, \\ Asaolu Sunday Samuel ${ }^{1}$ \\ ${ }^{1}$ Department of Chemistry, Ekiti State University, Ado-Ekiti, Nigeria \\ ${ }^{2}$ Department of Civil Engineering, University of Ibadan, Ibadan, Nigeria

\section{Email address:} \\ gloyaks@yahoo.com (O. G. Irenosen), adefemisamuel@yahoo.com (A. S. Oluyemi), femakus@yahoo.com (A. O. Korede), \\ ssasaolu@yahoo.com (A. S. Samuel)
}

\section{To cite this article:}

Oyakhilome Gloria Irenosen, Adefemi Samuel Oluyemi, Akinola Olufemi Korede, Asaolu Sunday Samuel. Integration of Physical, Chemical and Biological Methods for the Treatment of Palm Oil Mill Effluent. Science Journal of Analytical Chemistry.

Vol. 2, No. 2, 2014, pp. 7-10. doi: 10.11648/j.sjac.20140202.11

\begin{abstract}
Physico-chemical properties of Palm oil mill effluent (POME) were reduced by integrating physical, chemical and biological treatments to produce high quality effluent that can be discharged into the environment without causing any trepidation. This treatment technique recorded significant percentage reduction at each stage in all the measured parameters and the percentage reduction of all the measured parameters increased from stage 1 to stage 4 except nitrate-nitrogen concentration that decreased from stage 3 to stage 4 . The average values of Temp $\left(0^{\circ} \mathrm{C}\right), \mathrm{TS}, \mathrm{BOD}, \mathrm{COD}, \mathrm{NO}-\mathrm{N}, \mathrm{Cl}, \mathrm{K}, \mathrm{Zn}$, $\mathrm{Fe}, \mathrm{Ca}, \mathrm{Mg}$ in $\mathrm{mg} / \mathrm{L}$ of the raw POME are 36.00, 84.34, 72.10, 96.66, 32.34, 120.00, 14.45, 8.14, 68.80, 13.30 and 12.43 while the percentage reduction values at the last stage of treatment are $18.6 \%, 91.7 \%, 93.3 \%, 89.3 \%, 85.8 \%, 82.5 \%, 77.9 \%$, $77.3 \%, 94.3 \%, 90.8 \%$ and $85.9 \%$ respectively. At the end of the analysis, the concentrations of the parameters after treatment were in conformity with the minimum acceptable standards of FEPA and WHO.
\end{abstract}

Keywords: POME, Biological, Chemical, Percentage Reduction, Quality, Treatment

\section{Introduction}

Palm oil is one of the two most important vegetable oils in the world's oil and fats market. The extraction and purification processes generate different types of waste generally known as palm oil mill effluent (POME). Palm oil mill effluent is a thick brownish viscous liquid waste which is non-toxic but has unpleasant odour and contains soluble materials that may have significant negative effect on the environment (Wong et al, 2009).According to Ahmed et al (2005), the untreated POME contains 95-96\% water, $0.6-0.7 \%$ oil and $4-5 \%$ total solids, including $2-$ $4 \%$ suspended solids that are mainly debris from the palm oil fruit mesocarp. It was also reported that raw POME contains a high concentration of fatty acid, nitrogen compounds, starch, protein, plant tissues, high COD and BOD making it a hundred times more polluting than domestic sewage(Ahmed et al, 2003). Due to the environmental impact factors, industries should preserve the sustainability of the environment for the future generation. POME is a critical source of water pollution when released without treatment into rivers or lakes. The environmental impact of this waste water cannot be over emphasized; hence the need for treatment measures to reduce this impact before discharge.In the past, POME wasgenerally treated by various methods including anaerobic digestion resulting in methane as a value added product (Araffin et al, 2005; Yacob et al, 2006). The use of ponds system, aerobic bacteria, electro coagulants and other chemicals have also suffered various drawbacks.Biological method of wastewater treatment principally involves oxidation of all biodegradable organics by bacteria action.Complex biodegradable substances are broken down to less complex ones to produce cleaner and clearer effluent. However, non-biodegradable substances pass unaffected. In cases where there are toxic metals in the wastewater to be treated, the lives of the bacteria to effect the biodegradation of the waste are threatened by death and so little or no treatment occurs in the wastewater. Apart from this, nitrate and phosphate present in the wastewater are not well reduced by only biological method; these substances are known to cause problem of eutrophicationin 
water bodies (Ademoroti, 1996b). On the other hand, chemical method of wastewater treatment has shown sizeable quantity of sludge deposit. However, only a small quantity of ammonia is removed (Yacob et al, 2006). This reduction is insignificant when $2-3 \mathrm{mg} / \mathrm{L}$ of ammonia is known to have lethal effect on fish. Therefore, the drawbacks of the biological method are subdued in chemical method and vice versa, hence in this study, integrated physical, chemical and biological treatment was employed to adequately produce effluents that are superior to those from single methods.

\section{Materials and Methods}

\subsection{Sample Collection}

The samples were collected from a local factory site at Ikao, Owan East Local Government Area in Edo State, Nigeria. The site is located at latitudes $05^{\circ} 44^{\prime} \mathrm{N}$ and $07^{\circ} 34^{\prime} \mathrm{N}$ with a longitudes of $05^{\circ} 4^{\prime} \mathrm{E}$ and $06^{\circ} 45^{\prime} \mathrm{E}$ and it is low lying, except towards the north in the Greenwich Meridian. The palm oil mill effluent samples were collected and kept in a 10 litre polythene container which was closed tightly and transported to the laboratory to prevent it from undergoing biodegradation due to microorganism's action. The samples were preserved at temperature less than $40^{\circ} \mathrm{C}$ but above the freezing point prior to analysis. The sampling works were repeated for 4 batches. Pure cultures of Flavobacteria and Pseudomonas spp. were obtained from microbiology laboratory, Federal University of Technology, Akure.

\subsection{Sample Analysis}

The analysis was carried out in accordance with standard methods for the examination of water and waste water prescribed by Ademoroti (1996b) and APHA (1998). The study covered a period of three months (October - December, 2013), involving field measurements and laboratory experiments. Field measurements include tests for Dissolved Oxygen, temperature and $\mathrm{pH}$ while other parameters examined were conducted in the laboratory.The metals in the POME samples were analyzed using Atomic Absorption Spectrophotometer (Buck Scientific Model 200A).

The treatment of the POME was designed as a batch process involving four stages. Stage 1: filtration after boiling, stage 2: sedimentation using aluminum sulphate (alum), stage 3: clarification using hydrated iron (iii) chloride and stage 4: biological treatment (anaerobic) using flavobacteria and pseudomonas. In the first stage, 5 litres of POME were transferred into a stainless pot and boiled for 40 minutes. The boiled sample was allowed to cool to room temperature before filtering into a conical flask using Buchner funnel with the aid of a suction pump. $25 \mathrm{~g}$ of aluminum sulphate (alum) was added to the boiled sample in the flask; this was mixed thoroughly and left for two hours to allow sedimentation to occur. The fairly clear aluminum sulphate - POME solution was further clarified in the third stage by the addition of iron (iii) chloride and left for $1 \mathrm{hr}$. Then the cleared POME solution was transferred into a digestion flask for the fourth stage. Pure cultures of Pseudomonas spp and flavobacteria were inoculated into the flask and left in anaerobic condition at laboratory temperature for one week.

\section{Results and Discussion}

The average values of the measured physico-chemical parameters of the raw Palm oil mill effluent (POME) samples and the four stages of treatment are presented in Table 1 while the Percentage reductions for each stage are presented in Table 2.

The average value of the $\mathrm{pH}$ in the raw POME was 5.40, which is acidic. This may be due to the presence of high load of organic content undergoing partial decomposition during the palm oil extraction process. According to Oyakhilome et al, (2012), partial decomposition of organic matter produces organic acid (weak acid)capable of lowering the $\mathrm{pH}$ in the water. There was further decrease in the $\mathrm{pH}$ value (5.70)from stage 1 to stage 3 (Table 1) when the effluent was treated with aluminum sulphate (alum) and iron (iii) chloride, making it more acidic; an indication that the coagulants are acidic in nature. The introduction of biological treatment produced POME with almost neutral $\mathrm{pH}$ value of 7.2 , which is adequately within the standard limit $(6.5-8.0)$ for effluent of high quality that can be discharged into surface water (FEPA, 1997; WHO, 2001).The increase in the $\mathrm{pH}$ value via the application of biological treatment is not amazing, since it was reported that increase in water $\mathrm{pH}$ may be caused by accelerated algal growth, such as that which may occur during algal bloom and denitrification (Aiyesanmi et al, 2006). The averagetemperature for the untreated POME was $36.0^{\circ} \mathrm{C}$. There was a gradual reduction in temperature values from stage 1 to stage 4 during the treatment period and the $\%$ reduction in the last stage was $18.6 \%$.The high temperature observed in the untreated POME is not desirable by aquatic organisms as it lowers the amount of dissolved oxygen in the aquatic environment, thereby altering the rate of metabolism in the organisms. Based on the results of the $\%$ reduction, it is therefore established from this study, that high temperature in wastewater can be satisfactorily controlled by combination of biological and chemical treatments. Comparison of temperature values in this work with previous studies showed a similar trend in the percentage reduction from chemical treatment (Araffin et al, 2005) and biological treatment (Yacob et al, 2006) of POME. The average values $(\mathrm{mg} / \mathrm{L})$ of Total solids, $\mathrm{BOD}_{5}$ and COD of the raw POME were 84.34, 72.10 and 99.66 respectively while their $\%$ reduction values in stage 4 were $91.7 \%, 93.3 \%$ and $89.3 \%$ respectively. It was observed from this study that COD in the wastewater can be successfully reduced to an acceptable concentration by the use of chemical treatment alone. This can be seen from stages $2 \& 3$ of Table 2, where the use of alum and iron (iii) chloride yielded $62.2 \%$ and $77.2 \%$ respectively. However, 
the use of physical and chemical treatments reduced the value of $\mathrm{BOD}_{5}$ in the POME by $50 \%$. This $\%$ reduction could still generate problems of eutrophication and oxygen depletion in water bodies used as sink for such effluent. The application of biological treatment after the use of coagulants gave a quantitative reduction of $93.3 \%$ in BOD, resulting to a high quality effluent that is environmentally friendly and well within the guideline value of $5.0 \mathrm{mg} / \mathrm{L}$ (EPA, 2001).

The average concentrations of nitrate-nitrogen and chloride of the raw POME were $32.34 \mathrm{mg} / \mathrm{L}$ and $120.00 \mathrm{mg} / \mathrm{L}$ respectively. Considering the environmental implication of nitrate-nitrogen in aquatic medium, higher values recorded in this study than the limit value of $5 \mathrm{mg} / \mathrm{L}$ (DWAF, 1996) could be detrimental to aquatic organisms. The use of biological method for the treatment of nitratenitrogen in this study was not efficient, as there was aslight increase in the concentration from $4.20 \mathrm{mg} / \mathrm{L}$ to $4.60 \mathrm{mg} / \mathrm{L}$ in stages $3 \& 4$ of Table 1 . Chemical treatment in this case is effectively adequate to reduce the concentration of nitratenitrogen in Palm oil mill effluent as discovered in the \% reduction values of $15.0 \%, 50.0 \%, 87.0 \%$ and $85.8 \%$ covering stage 1 to stage 4 respectively. Relatively higher values and better treatment yield (Table 3 ) in the present investigation compared to previous study (Aisien et al, 2009) was recorded for TS, BOD and COD, although the percentage reduction in the treatment process assumed a common pattern.

The average concentrations of the metals $\mathrm{K}, \mathrm{Zn}, \mathrm{Fe}, \mathrm{Ca}$ and $\mathrm{Mg}$ in $\mathrm{mg} / \mathrm{L}$ of the raw effluent were $14.45,8.14,68.50$, 13.30 and 12.43 while their \% reduction values at the last stage were $77.9 \%, 73.3 \%, 94.3 \%, 90.8 \%$ and $85.5 \%$ respectively. The reduction of these metals in the POME was achieved by integrating physical, chemical and biological approaches. The biological treatment was more effective for $\mathrm{K}$ and $\mathrm{Zn}$ while reduction in the concentration of $\mathrm{Fe}, \mathrm{Ca}$, and $\mathrm{Mg}$ complied more with chemical treatment. The concentrations of the metals examined in this study were lower than those investigated by Aisien et al (2009) and Wong et al (2009), while the physico-chemical parameters in this research recorded higher values than obtained by Aisien et al (2009). The variation in the concentrations of the measured parameters could be associated with the ageand type of the palm fruit, differences in the processing techniques of the raw palm fruit as well as the quantity processed (Phutdhawong and Buddhazukh, 2007). In terms of percentage reduction, there is a good concordance between the results of the present study and the values produced by Ademoroti (1996b) in his study of wastewater treatment. All the parameters examined in the present work were successfully reduced to their safe limit value for high quality effluent that can be discharged into aquatic system. Therefore, the aim of this study, which was based on producing quality POME that will be environmentally accommodated with minimal or no immediate or persistence adverse effect, was achieved.
Table 1. Physico-chemical properties of Palm Oil Mill Effluent

\begin{tabular}{llllll}
\hline \multirow{2}{*}{ PARAMETERS } & \multirow{0}{*}{} & $\begin{array}{c}\text { STAGE } \\
\mathbf{1}\end{array}$ & $\begin{array}{c}\text { STAGE } \\
\mathbf{2}\end{array}$ & $\begin{array}{c}\text { STAGE } \\
\mathbf{3}\end{array}$ & $\begin{array}{c}\text { STAGE } \\
\mathbf{4}\end{array}$ \\
\hline $\mathrm{pH}$ & 5.40 & 6.50 & 6.10 & 5.70 & 7.20 \\
Temperature & 36.00 & 32.40 & 31.00 & 30.40 & 29.30 \\
$\left(0^{\circ} \mathrm{C}\right)$ & & & & & \\
$\mathrm{T} . \mathrm{Solid}(\mathrm{mg} / \mathrm{L})$ & 84.34 & 51.10 & 36.24 & 31.52 & 7.50 \\
$\mathrm{BOD}(\mathrm{mg} / \mathrm{L})$ & 72.10 & 58.35 & 45.08 & 35.00 & 5.02 \\
$\mathrm{COD}(\mathrm{mg} / \mathrm{L})$ & 96.66 & 75.66 & 36.52 & 22.00 & 10.30 \\
$\mathrm{NO}^{3-} \mathrm{N}(\mathrm{mg} / \mathrm{L})$ & 32.34 & 27.50 & 16.10 & 4.20 & 4.60 \\
$\mathrm{Cl}^{-}(\mathrm{mg} / \mathrm{L})$ & 120.00 & 80.10 & 50,30 & 33.00 & 21.10 \\
$\mathrm{~K}^{+}(\mathrm{mg} / \mathrm{L})$ & 14.45 & 13.90 & 10.05 & 7.24 & 3.20 \\
$\mathrm{Zn}^{2+}(\mathrm{mg} / \mathrm{L})$ & 8.14 & 8.00 & 5.43 & 4.00 & 1.85 \\
$\mathrm{Fe}^{2+}(\mathrm{mg} / \mathrm{L})$ & 68.80 & 51.34 & 26.80 & 16.30 & 3.93 \\
$\mathrm{Ca}^{2+}(\mathrm{mg} / \mathrm{L})$ & 13.30 & 10.13 & 7.19 & 4.69 & 1.23 \\
$\mathrm{Mg}^{2+}(\mathrm{mg} / \mathrm{L})$ & 12.43 & 10.20 & 3.00 & 1.80 & 1.75 \\
\hline
\end{tabular}

Table 2. Percentage reduction of physico-chemical properties of palm oil mill effluent

\begin{tabular}{|c|c|c|c|c|}
\hline PARAMETERS & STAGE I & STAGE 2 & $\begin{array}{c}\text { STAGE } \\
\mathbf{3}\end{array}$ & $\begin{array}{c}\text { STAGE } \\
4\end{array}$ \\
\hline $\mathrm{pH}$ & $\begin{array}{l}\text { Slightly } \\
\text { acidic }\end{array}$ & $\begin{array}{l}\text { V. slightly } \\
\text { acidic }\end{array}$ & Acidic & $\begin{array}{l}\text { Almost } \\
\text { neutral }\end{array}$ \\
\hline Temperature $\left(0^{\circ} \mathrm{C}\right)$ & 10.0 & 13.9 & 15.6 & 18.6 \\
\hline T.Solid (mg/L) & 39.4 & 57.0 & 62.6 & 91.7 \\
\hline BOD $(\mathrm{mg} / \mathrm{L})$ & 19.1 & 37.5 & 51.5 & 93.3 \\
\hline $\mathrm{COD}(\mathrm{mg} / \mathrm{L})$ & 21.7 & 62.2 & 77.2 & 89.3 \\
\hline $\mathrm{NO}^{3-} \mathrm{N}(\mathrm{mg} / \mathrm{L})$ & 15.0 & 50.0 & 87.0 & 85.8 \\
\hline $\mathrm{Cl}^{-}(\mathrm{mg} / \mathrm{L})$ & 33.3 & 58.1 & 72.5 & 82.5 \\
\hline $\mathrm{K}^{+}(\mathrm{mg} / \mathrm{L})$ & 3.8 & 30.4 & 49.9 & 77.9 \\
\hline $\mathrm{Zn}^{2+}(\mathrm{mg} / \mathrm{L})$ & 1.7 & 33.3 & 50.9 & 77.3 \\
\hline $\mathrm{Fe}^{2+}(\mathrm{mg} / \mathrm{L})$ & 25.4 & 61.0 & 76.3 & 94.3 \\
\hline $\mathrm{Ca}^{2+}(\mathrm{mg} / \mathrm{L})$ & 23.8 & 45.9 & 64.7 & 90.8 \\
\hline $\mathrm{Mg}^{2+}(\mathrm{mg} / \mathrm{L})$ & 17.9 & 75.9 & 85.5 & 85.9 \\
\hline
\end{tabular}

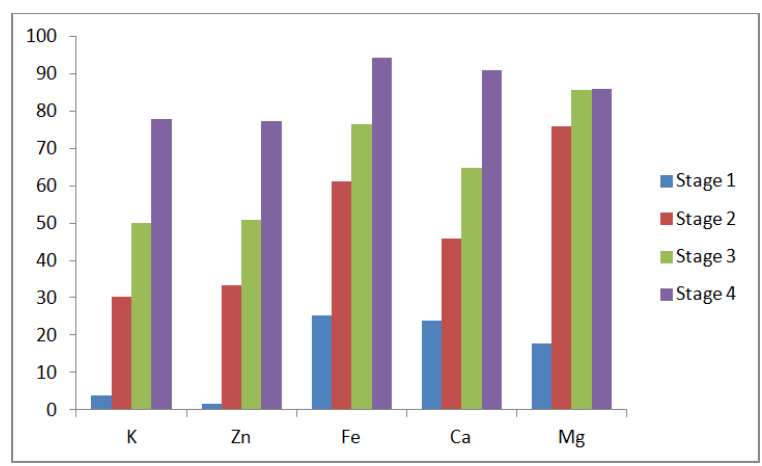

Fig 1. Percentage reduction ofanalyzed metals presentin the POME

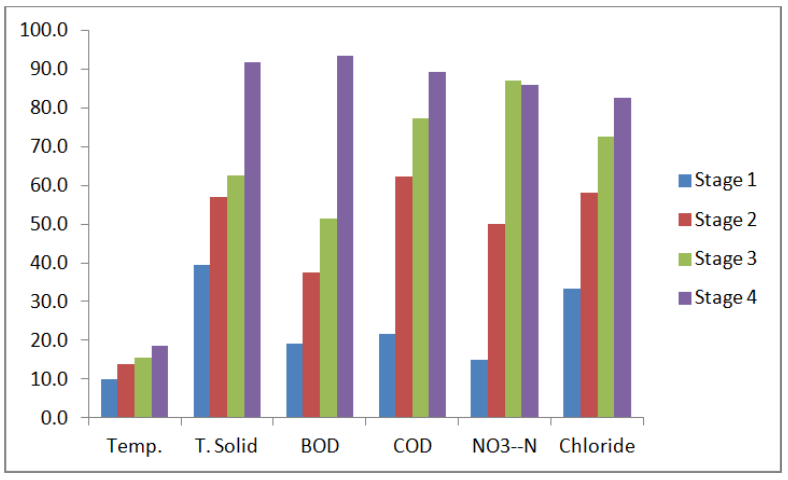

Fig 2. Percentage reduction in POME physico-chemical parameters 


\section{Conclusion}

Palm oil mill effluent is a critical source of water pollution when released without treatment into local rivers and lakes. The effluent has to be thoroughly treated so that it can be tolerated by organisms present in the receiving system. This prompted the use of physical, chemical and biological methods of treatment in this study as the drawbacks of single methods were successfully taken care of. The percentage reduction of all the measured parameters increased from stagel to stage 4 except nitrate-nitrogen concentration that decreased from stage 3 to stage 4 . It was observed that the method recorded significant reduction in all measured parameters, thereby producing concentrations well within the guideline values of the parameters.

\section{Acknowledgement}

The authors sincerely acknowledge the management of Phemakus Construction Company Ltd for the financial support during the period of the research.

\section{References}

[1] Ademoroti, C.M.A. (1996b). Standard Methods for Water and Effluent Analysis. Foludex Prenmvss Ltd. Ibadan, Nigeria. 182pp.

[2] Ahmed, A.L., Ismail, S. and Bhatia, S. (2003). "Removal of suspended Solids and Residual Oil from Palm Oil Mill Effluent”. J. Chem. Tech. and Biotech. 78: 971-978.

[3] Ahmed, A.L., Ismail, S. and Bhatia, S. (2005). "Membrane Treatment for Palm Oil Mill Effluent: Effect of Trans membrane Pressure and cross flow velocity". Journal on Desalination, 179, pp. 245-255.

[4] Aisien, F.A., Ojarikre, A.A., Aisien, E.T. (2009). Batch Treatment of Palm Oil Mill Effluent. Advanced Material Research. Vols. 62-64, pp759-762.
[5] Aiyesanmi, A.F., Ipinmoroti, K.O. and Adeeyinwo, C.E. (2006); Baseline water quality status of rivers within Okitipupasoutheast belt of the bituminous sand field of Nigeria. Nig. J. Sci. 40, 62 -71.

[6] APHA (1998). Standard Methods for the Examination of Water and Wastewater, 20th ed. American Public Health Association, American Water Works Association, Water Polution Control Federation, Washington, USA.

[7] Araffin, A., Shatat Raid, S.A., Norulaini, A.R.N., Omar, A.K.M. (2005). Synthetic Polyelectrolytes of varying charge densities but similar molar mass based on Acrylamide and their applications on palm oil mill effluent treatment desalination. 173: 201-208.

[8] EPA, (2001): Parameters of Water Quality: Interpretation and Standards. Environmental Protection Agency, Ireland.Pp133.

[9] Federal Environmental Protection Agency (1997). "Guideline and Standard for Environmental Impact Assessment in Nigeria”. Pp 87-95.

[10] Oyakhilome, G.I., Aiyesanmi, A.F. and Akharaiyi, F.C. (2012). Water quality assessment of the Owena Multipurpose dam, Ondo State, Southwestern Nigeria. Journ. Envir. Protection, 3 (1), 14-25

[11] Phutdhawong, W. and Buddhasukh, D. (2007). Application of Electrocoagulation. 1st Ed. Chotana Print. Co. Ltd; Chiangmai.Pp. 22-24.

[12] WHO(2008). Guidelines for drinking - water quality, 3rd Ed. World Health Organization, 20 Avenue Appia, 1211 Geneva 27, Switzerland. 688p.

[13] Wong, Y.S., Kadir, M.O.A.B. and Teng, T.L. (2009). Biological kinetics evaluation of anaerobic stabilization pond treatment of Palm oil mill effluent. BioresourTechnol, $100,4969-4975$.

[14] Yacobs, S., Hassan, M., Shurai, Y., Wakisaka, M., Subash, S. (2006). Baseline study of methane emission from anaerobic ponds of Palm Oil Mill Effluent treatment. Sci. Total Environ. 366: 